\title{
Insecticide Resistance in Field Population of Cotton Leaf Hopper, Amrasca devastans (Dist.) in Guntur, Andhra Pradesh, India
}

\author{
M. Sesha MahaLakshmi* and N. V. V. S. D. Prasad \\ Regional Agricultural Research Station, Lam, ANGRAU, Guntur, Andhra Pradesh, India \\ *Corresponding author
}

\begin{tabular}{l} 
Ke y w o r d s \\
$\begin{array}{l}\text { Neonicotinoids, } \\
\text { Cotton leafhopper, } \\
\text { Insecticide } \\
\text { resistance }\end{array}$ \\
\hline Article Info \\
\hline $\begin{array}{l}\text { Accepted: } \\
\text { 21 May } 2020 \\
\text { Available Online: } \\
\text { 10 June } 2020\end{array}$ \\
\hline
\end{tabular}

\section{A B S T R A C T}

The bioassay was carried out in the laboratory at Regional Agricultural Research Station, Lam, Guntur at normal room temperature and humidity conditions during 2016-17. The commonly used neonicotinoid insecticides viz., imidacloprid 17.8 SL, acetamiprid $20 \mathrm{SP}$, thiamethoxam $25 \mathrm{WG}$ and two organophosphate insecticides viz., acephate $75 \mathrm{SP}$ and monocrotophos $36 \mathrm{SL}$ were selected as test insecticides. The per cent mortality at $48 \mathrm{hrs}$ after treatment was low with neonicotinoids when compared to organophosphates. The resistance ratio for imidacloprid, acetamiprid and thiamethoxam was 8.4, 12.9 and 9.4 folds, respectively. But, for organophosphate insecticides such as acephate and monocrotophos, it was only 2.3 fold and 2.9 fold, respectively. The results indicated that the leafhopper population of Guntur developed slight resistance to neonicotinoids such as imidacloprid 17.8 SL, acetamiprid $20 \quad$ SP and thiamethoxam $25 \mathrm{WG}$ when compared to organophosphate insecticides viz., acephate 75 SP and monocrotophos 36 SL.

\section{Introduction}

The major biotic constraint in $\mathrm{Bt}$ cotton is the occurrence of sucking pests to attain absolute yield potential from Bt cotton hybrids. The cotton leaf hopper, Amrasca devastans (Distant) (Homoptera: Cicadellidae) is posing a serious limitation to seed cotton yield which occur throughout the crop growth period in Andhra Pradesh. The leafhoppers can cause 21.2 per cent loss in yield (Bhosle et al., 2009) and can reduce upto $309 \mathrm{~kg} / \mathrm{ha}$ in quantity of seed yield (Murugesan and Kavitha, 2010). Farmers mostly depend upon insecticides belonging to different groups to keep the crop free from leafhoppers and other sucking pests.

The better efficacy of neonicotinoids such as imidacloprid, acetamiprid and thiamethoxam over conventional insecticides against sucking pests was well documented earlier by many of the researchers. However, few reports revealed that some of the commonly used 
neonicotinoids are not able to suppress the leafhopper population under field conditions. Development of resistance to neonicotinoids is a major constraint for sucking pest management in cotton which might be due to indiscriminate use of neonicotinoids at higher doses.

A few instances of control failures were also reported by neonicotinoids at their recommended doses and cotton farmers are using higher doses than recommended doses to manage the leafhopper menace (Kalra et al., 2001; Chalam and Subbaratnam, 1999; Honnappagouda et al., 2011; Chaudhari et al., 2015). Hence, an experiment was conducted with an objective to ascertain the resistance development in the leafhopper population of Guntur, Andhra Pradesh to neonicotinoids.

\section{Materials and Methods}

The bioassay was carried out in the laboratory at Regional Agricultural Research Station, Lam, Guntur at normal room temperature and humidity conditions during August and September, 2016. The commonly used neonicotinoid insecticides viz., imidacloprid 17.8 SL, acetamiprid $20 \mathrm{SP}$, thiamethoxam 25 WG and two organophosphate insecticides viz., acephate 75 SP and monocrotophos 36 SL were selected as test insecticides.

The details of test insecticides with their chemical, trade name and source are furnished in Table 1. The test insecticides were procured from the market and required dilutions were prepared from the formulated products of the insecticide using distilled water.

The required concentration of test insecticides was freshly prepared during each bioassay and stored in cool and dark place for further use. The leafhoppers were collected from the unsprayed fields were reared in laboratory and the first generation nymphs were exposed to recommended concentration of each test insecticide. The experiment was conducted in completely randomised block design (CRBD) with three replications and 20 nymphs were used for each concentration of test insecticide. Bioassays were conducted through the leaf dip bioassay method (IRAC method No. 8). Plastic jars with perforated lid were selected to conduct bioassay studies.

Fresh cotton leaves were plucked from the unsprayed cotton field and cleaned with tap water followed by distilled water and wiped off with cotton swab. The leaves were dipped in the insecticide solution for 10 seconds holding the leaf petiole and allowed to dry for 5-10 minutes. Then the leaves were placed in small plastic cup containing 10 per cent sucrose solution to maintain the turgidity of the cotton leaf and 20 nymphs were released in each jar and were covered with cotton cloth.

A control was maintained where in the leaves were dipped in the distilled water only. At 48 hours after treatment the treated leaf was taken out from the plastic cup with utmost care and the mortality of leafhopper was recorded in all test insecticides. Nymphs which did not respond to probing (moribund) were also considered as dead. Percentage of mortality for the recommended concentration of test insecticide and control were computed and corrected per cent mortality was calculated by Abbott's formula (Abbott, 1925). Whenever the mortality in control exceeded 20 per cent, the experiment was repeated again.

Corrected per cent mortality $=(\mathrm{T}-\mathrm{C}) /(100-\mathrm{C})$ $\times 100$

Where, $\mathrm{T}=$ Per cent mortality in treatment, $\mathrm{C}=$ Per cent mortality in control

The corrected mortality data of each test 
insecticide was subjected to probit analysis using EPA probit analysis program for calculation of LC 50 and LC 90. Later, resistance ratio for each insecticide was calculated using the formula as given below.

Resistance ratio $(\mathrm{RR})=\mathrm{LC}_{90} /$ Recommended dose

\section{Results and Discussion}

The mortality of leafhopper nymphs was recorded at 48 hrs after treatment from all the insecticides at recommended doses of respective insecticides. The per cent mortality was only 33.3 per cent with acetamiprid 20 SP @ 200 ppm and 46.7 per cent with imidacloprid 17.8 SL @ 400 ppm at 48 hrs after treatment. While, the other neonicotinoid, thiamethoxam 25 WG @200 ppm recorded 66.7 per cent mortality of leafhopper nymphs. But, the organophosphates i.e acephate 75 SP @ 1500 ppm and monocrotophos 36 SL @ 2000 ppm recorded 86.7 per cent mortality at $48 \mathrm{hrs}$ after treatment (Table 2). Acephate and monocrotophos gave more than 85 per cent mortality of leafhoppers at $48 \mathrm{hrs}$ of treatment, while neonicotinoids such as imidacloprid and acetamiprid were able to suppress less than 50 per cent population only and it was below 70 per cent for thiamethoxam indicating the development of resistance in leafhopper to the most commonly used neonicotinoids. Thus it is evident that there was a decrease in toxicity of imidacloprid, acetamiprid and thiamethoxam against leafhoppers when compared to conventional organophosphates. It was further indicated by the increase in their LC 50 values i.e 832, 571 and 577 ppm respectively, for imidacloprid, acetamiprid and thiamethoxam, respectively. The LC50 values were 2-3 times higher than the recommended doses for all the three neonicotinoids. The resistance ratio for imidacloprid, acetamiprid and thiamethoxam was 8.4, 12.9 and 9.4 folds, respectively. But, organophosphate insecticides such as acephate and monocrotophos recorded only 2.3 and 2.9 fold resistant ratio, respectively (Table 2 ). The results indicated that the leafhopper population of Guntur developed resistance against neonicotinoids such as imidacloprid 17.8 SL, acetamiprid 20 SP and thiamethoxam $25 \mathrm{WG}$ when compared to organophosphate insecticides viz., acephate $75 \mathrm{SP}$ and monocrotophos $36 \mathrm{SL}$.

At a decade back, resistance was reported in leafhoppers to many of commonly used insecticides such as dimethoate, phosphamidon, demeton methyl, cypermethrin, fenvalerate, malathion and monocrotophos (Karla et al., 2001; VijayaKumar et al., 2004; RamSingh and Jaglan, 2005; Jhansi et al., 2004). Leafhoppers developed resistance to endosulfan, monocrotophos, cypermethrin, phosphamidon, dimethoate, methyl demeton and acephate (Jeya Pradeepa and Regupathy, 2002). While, imidacloprid and other neonicotinoids were reported as highly effective against sucking pests in cotton (VijayaKumar et al., 2004; Ram Singh and Jaglan, 2005). But at present, many reports were available on development of resistance in leafhoppers against neonicotinoids. Chaudhari et al., (2015) reported very high resistance ratios such as 108.68, 78.24 and 25.96 fold for imidacloprid, thiamethoxam and acetamiprid, respectively when compared to 29.04 and 9.29 folds for monocrotophos and acephate, respectively from Surat. Similarly, Preetha et al., (2014) reported that the level of resistance was 6.67 to 15.38 for imidacloprid, 3.33 to 15.09 for thiamethoxam and 5.00 to 20.00 for acetamiprid in different places of Tamilnadu. Earlier, Honnappagouda et al., (2011) reported that imidacloprid was effective for three days only against okra leafhopper and it was failed to 
check the leafhopper population at seven days after spraying and the population again crossed the ETL after seven days. The resistance was 110 fold for acephate, 54 folds for monocrotophos, 2500 folds for thiamethoxam, 5450 folds for imidacloprid, and the resistance was highest in central India when compared to north India (Anon., 2011).

Later, Kshirsagar et al., (2012) also reported higher resistance ratios for imidacloprid (23.41 folds) and acetamiprid (19.08 folds) when compared to dimethoate (5.21 folds) in cotton leafhoppers. They opined that continuous use of neonicotinoids against the cotton leafhopper in the last decade created high selection pressure which leads to development of resistance against the neonicotinoids. In contrast, Sandhu and Kang (2015) reported that imidacloprid was proved as highly toxic followed by acetamiprid and dimethoate with minimum LC50 values. In contrast, the order of toxicity of insecticides against leafhoppers was found to be imidacloprid > acetamiprid > dimethoate > monocrotophos > triazophos based on LC50 values obtained and there are no serious levels of resistance with respect to neonicotinoids in Punjab.

Table.1 Details of the Insecticides selected for the study

\begin{tabular}{|c|c|c|c|}
\hline S.No & Insecticide & Trade name & Manufacturing company \\
\hline $\mathbf{1}$ & Imidacloprid 17.8 SL & Confidor & Bayer \\
\hline $\mathbf{2}$ & Acetameprid 20 SP & Rekord & Dupont \\
\hline $\mathbf{3}$ & Thiamethoxam 25 WG & Actara & Syngenta \\
\hline $\mathbf{4}$ & Acephate 75 SP & Tamaron gold & Bayer \\
\hline $\mathbf{5}$ & Monocrotophos 36 SL & Bilphos & Bayer \\
\hline
\end{tabular}

Table.2 Insecticide resistance in Guntur population of cotton leafhopper 16-17

\begin{tabular}{|c|c|c|c|c|c|c|c|}
\hline \multirow[t]{2}{*}{ S.No } & \multirow[t]{2}{*}{ Insecticide } & \multirow{2}{*}{$\begin{array}{c}\text { Recomm } \\
\text { ended } \\
\text { dose } \\
(\mathrm{ppm})\end{array}$} & \multirow{2}{*}{$\begin{array}{l}\text { Mortality of } \\
\text { leaf hoppers } \\
\text { at } 48 \mathrm{hrs} \\
\text { after } \\
\text { treatment }\end{array}$} & \multicolumn{2}{|c|}{ ppm } & \multirow[t]{2}{*}{$\mathbf{R}^{2}$} & \multirow{2}{*}{$\begin{array}{c}\text { Resistance } \\
\text { Ratio (LC } \text { C }_{90} / \\
\text { Recommended } \\
\text { dose) }\end{array}$} \\
\hline & & & & $\begin{array}{c}L^{L} C_{50} \\
(95 \% \mathrm{FL})\end{array}$ & $\begin{array}{c}\mathbf{L C}_{90} \\
(\mathbf{9 5 \%} \mathbf{F L})\end{array}$ & & \\
\hline 1 & $\begin{array}{l}\text { Imidacloprid } \\
17.8 \mathrm{SL}\end{array}$ & 400 & 46.7 & $\begin{array}{c}832 \\
(554-1248)\end{array}$ & $\begin{array}{c}3354 \\
(2105-4739)\end{array}$ & 0.98 & 8.4 \\
\hline 2 & $\begin{array}{l}\text { Acetameprid } \\
20 \mathrm{SP}\end{array}$ & 200 & 33.3 & $\begin{array}{c}571 \\
(364-895)\end{array}$ & $\begin{array}{c}2576 \\
(1644-4035)\end{array}$ & 0.88 & 12.9 \\
\hline 3 & $\begin{array}{c}\text { Thiamethoxam } \\
25 \text { WG }\end{array}$ & 200 & 66.7 & $\begin{array}{c}577 \\
(410-812)\end{array}$ & $\begin{array}{c}1879 \\
(1336-2642)\end{array}$ & 0.97 & 9.4 \\
\hline 4 & $\begin{array}{l}\text { Acephate } \\
75 \mathrm{SP}\end{array}$ & 1500 & 86.7 & $\begin{array}{c}1381 \\
(1035-1843)\end{array}$ & $\begin{array}{c}3467 \\
(2598-4626)\end{array}$ & 0.98 & 2.3 \\
\hline 5 & $\begin{array}{c}\text { Monocrotophos } \\
\text { 36 SL }\end{array}$ & 1600 & 86.7 & $\begin{array}{c}1936 \\
(1470-2551)\end{array}$ & $\begin{array}{c}4642 \\
(3524-6114)\end{array}$ & 0.99 & 2.9 \\
\hline
\end{tabular}


After introduction of neonicotinoids, the use of organophosphate insecticides which are broad spectrum in activity was reduced to a greater extent during the past decade, hence the development of resistance might be reversed or slowdown in leafhoppers to organophosphates. In similar way, it is necessary to trim down the use of neonicotinoids currently to check or decelerate the development of resistance against neonicotinoids in leafhoppers.

The continuous and indiscriminate use of neonicotinoids at higher doses might be the basis for development of resistance in cotton leafhoppers due to high selection pressure. In general, $\mathrm{Bt}$ cotton seed treated with imidacloprid is only available for sale.

After germination, farmers generally relay upon neonicotinoids only to manage the sucking pests in cotton which might be creating high selection pressure for neonicotinoids in sucking pests of cotton and may be leading to the development of resistance in leafhoppers against neonicotinoids.

Hence, awareness should be created among the farming community to avoid neonicotinoids at early stages of crop growth as an insecticide resistance management strategy to reduce the development of resistance to neonicotinoids in leafhoppers.

The farmers should move away from use of neonicotinoids at early stages of crop growth to either organophosphate or carbamate-based products for foliar sprays to curtail sucking pests.

\section{Acknowledgement}

Authors are extremely thankful to ANGRAU, Guntur for providing funds, land, inputs and man power for conducting the trial.

\section{References}

Abbott, W.S., 1925. A method of computing the effectiveness of an insecticide. Journal of economic entomology, 18: 265-267

Anonymous, 2011. Annual Report 2009-10 Technology Mission on Cotton, Published by Director and Member Secretary, CICR regional Station, Coimbatore, Tamilnadu, India. Pp:5759.

Bhosle, B.B., More, D.G., Patange, N.R., Sharma, O.P. and Bambawale, O.M. 2009. Efficacy of different seed dressers against early season sucking pest of cotton. Pesticide Research Journal, 21(1): 75-79.

Chalam, M. S. and Subbaratnam, G. V. 1999. Insecticide resistance in cotton leafhopper, Amrasca biguttula biguttula (Ishida) in Andhra Pradesh. Pest Management and Economic Zoology., 7: 105-110.

Chaudhari, V. K., Desai, H. R. and Patel, N. M. 2015. Assessment of the insecticide resistance build up on cotton leafhopper, Amrasca biguttula biguttula (Ishida). International Journal of Advanced Multidisciplinary Research, 2(11): 4-8.

Honnappagouda, K., Bheemanna, M. and Suhas Yelshetty, 2011. Current efficacy status of imidacloprid formulations against okra leafhopper, Amrasca biguttula biguttula. Indian Journal of Plant Protection, 39(1): 70-72.

Jeya Pradeepa S. and Regupathy, A., 2002. Generating base line data for insecticide resistance monitoring in cotton leafhopper, Amrasca devastans (Distant). Resistant Pest Management Newsletter, 11(2): 4-5.

Jhansi, K, Radhika, P. and Subbaratnam, G. V. 2004. Insecticide resistance in insect pests of cotton in Andhra Pradesh. 
Paper presented in International Symposium on "Strategies for sustainable cotton production- A global Vision", Crop protection, 23-25 November, 2004, UAS, Dhrawad, Karnataka, India. 198-200.

Kalra, V. K., Singh Ram, Saini, R. K., Rohilla, H. R., Jaglan, R. S., Chauhan, R. and Sharma, S. S., 2001. Occurrence of insecticide resistance in leafhopper, Amrasca biguttula biguttula (Ishida) on Okra. Journal of Entomological Research, 25(4): 263-265.

Kshirsagar, S. D., Satpute, N. S. and Moharil, M. P. 2012. Monitoring of insecticide resistance in cotton leafhopper, Amrasca biguttula bigittula (Ishida). Annual Journal of Plant Portection Sciences, 20(2): 283-286.

Murugesan, N and Kavitha, A. 2010. Host plant resistance in cotton accessions to the leafhopper, Amrasca devastans (Distant). Journal of Biopesticides, 3(3): 526-533.

Preetha, G. Stanley, J., Manoharan T and
Kuttalam, S. 2014. Baseline toxicity of chloronicotinyls against cotton leafhopper, Amrasca biguttula biguttula, and detection of insecticide resistance. Archives of Phytopathology and Plant Protection, 47 (17): 20952105.

Ram Singh and Jaglan, R. S. 2005. development and management of Insecticide resistance in cotton whitefly and leafhopper - A review. Agricultural Reviews, 26 (3): 229 - 234.

Sandhu R K and Kang B K 2015. status of insecticide resistance in leafhopper, Amrasca biguttula biguttula (Ishida) on cotton. The Bioscan, 10(4): 1441-1444.

Vijaya Kumar, Fakruddin, B, Krishna Reddy, K. B. and Patil, B. V. 2004. Detection of insecticide resistance in field populations of cotton leafhopper, Amrasca bigittula bigittula in South India through in situ bioassay method. Resistant pest management News letter, 14:18-19.

\section{How to cite this article:}

Sesha MahaLakshmi, M. and Prasad, N. V. V. S. D. 2020. Insecticide Resistance in Field Population of Cotton Leaf Hopper, Amrasca devastans (Dist.) in Guntur, Andhra Pradesh, India. Int.J.Curr.Microbiol.App.Sci. 9(06): 3006-3011. doi: https://doi.org/10.20546/ijcmas.2020.906.361 